УДК 339.138(479.22)

\title{
MARKETING DEVELOPMENT PROBLEMS IN GEORGIA
}

\author{
Katamadze G. Sh.
}

Анотація. Методологічною основою дослідження є діалектичні принципи, використання яких дозволило виявити форми, властиві маркетинговим процесам і факторам, що перешкоджають їх розвитку. В процесі дослідження використані методи аналізу та синтезу, узагальнення маркетингових проблем.

Дослідження показало, що в Грузії існують такі проблеми, як низька споживча спроможність населення, низький рівень ємності ринку, низький рівень конкурентоспроможності цін на грузинські продукти, незаконна вулична торгівля неякісними фальсифікованими товарами, без урахування чисельності дрібних торговців, проблема вилучення податків, проблем продажу вітчизняної продукції закордоном.

Для усунення проблем у сфері маркетингу Грузії необхідно вжити наступні заходи: сфера дослідження соціального маркетингу повинна стимулювати розвиток бізнесу з урахуванням специфіки поведінки споживачів у кризовий період; для вирішення соціальних проблем необхідна консолідація держави, бізнесу та населення; щоб реалізувати соціальні маркетингові програми, необхідно вибрати партнера; для вирішення соціальних проблем необхідно провести вибірку цільових груп споживачів для сприйняття соціальних ідей, щоб реалізувати пакет соціальних заходів; необхідно створити кооперативи поблизу місця перебування фермерів 3 метою більш ефективного вирощування сільськогосподарської продукції та іiї обробки в агропромислових центрах, а в подальшому для реалізації у фастфудах, кафе, ресторанах, готелях, супермаркетах та інших торговельних мережах.

Ключові слова: маркетингова стратегія, концепція маркетингу, соціальний маркетинг, маркетингова довкілля, маркетингові проблеми.

Аннотация. Методологической основой исследования есть диалектические принципы, что сделало возможным выявление форм, свойственных маркетинговым процессам и факторов, препятствующих их развитию. В процессе исследования были использованы методы анализа и синтеза, обобщения маркетинговых проблем.

Исследование показало, что в Грузии существуют проблемы такого рода, как низкая покупательная способность населения, низкий уровень емкости рынка, низкая уровень конкурентоспособности цен грузинской продукции, незаконная уличная торговля некачественными фальсифицированными товарами, без учета численности мелких торговцев, проблема изъятия налогов, проблемы продажи отечественной продукции за рубежом.

Для устранения проблем в области развития маркетинга в Грузии необходимо принять следующие меры: сфера исследования социального маркетинга должна стимулировать развитие бизнеса с учетом специфики поведения потребителей в кризисном периоде; для устранения социальных проблем необходима консолидация государства, бизнеса и населения; чтобы реализовать социальные маркетинговые программы; для решения социальных проблем необходимо произвести отбор целевых групп потребителей для восприятия социальных идеи, чтобы реализовать пакет социальных мероприятий; необходимо создавать кооперативы вблизи места жительства фермеров с целью более эффективного выращивания аграрной продукции и ее обработки в агропромышленных центрах, а в дальнейшем для реализации в фастфудах, кафе, ресторанах, гостиницах, супермаркетах и других торговых сетях.

Ключевые слова: маркетинговая стратегия, концепция маркетинга, социальный маркетинг, маркетинговая окружающая среда, маркетинговые проблемы. 
The problem's setting. The study revealed that there are some problems in Georgian marketing sphere, such as: low purchasing power of the population, low level of market capacity, local production price competitiveness low level, unauthorized external trade, substandard, counterfeit goods trade, small traders lack of registering, including taxes payment problems from problem, our products overseas sales and other problems.

In the modern world under the conditions of globalization and internationalization of the economy to sell Georgian products abroad is becoming more difficult. In order to eliminate this problem, it is necessary for our country's government to carry out customer wishes and tastes oriented marketing strategy. Marketing modern concept in Georgia is buyers demandoriented doctrine, which aims to research purchase capable demand regulating mechanism fundamental study.

The subject of the article. The subject of the article is Georgian Marketing Environment.

The aim of the article. The purpose of the article is to disclose problems in marketing sphere in Georgia and outline their solving measures.

The article methodology (methods). The methodological bases of the study are dialectic principles, which have made possible to reveal marketing process characteristics, forms, determining obstructing factors of their development. In the article marketing problem generalization, analysis and synthesis methods have been used.

The main results and its grounding. Georgia's marketing environment is created under unstable macroeconomic conditions. Therefore, in our country the goods, which will be definitely sold are produced. The product range is limited, the production process inflexible. When determining the product price are considered expenses, which the consumer incurs during the purchasing operation.

Products competitiveness in Georgia is determined by the user's ability to give priority to certain items. Unfortunately, in our country there fundamental marketing researches are not conducted, and it would be possible to study market condition, customers and competitors' behavior modeling. Unfortunately, in Georgia for a Competitive foreground is heading forward not only its technological advantages, but also - design.

Our country's marketing concept, as business confidence ethics, should be focused on the customer. In this regard, there are two basic approaches to the marketing concept: Western and Asian. Their difference lies mainly in the fact that the marketing Asian model is focused on market. It considers that customers' feelings and needs, and the marketing concept of Western model uses manipulation in order to achieve their own goals. The main task of Western marketing is to convince potential customers and to entice them, while the main task of Asian marketing is to satisfy their demand.

According to present situation in Georgia, Georgian marketing conception establishment should be based on those two directions in which our customer's consumer specifics will be provided. We can note the important fact that the country's economy and business links determine independent or competitive environment, which is reflected in marketing development in the process of its implementing. Marketing concept in Georgia should satisfy customers' interests. It means what the level of economic development of the country is, the same development level will be in marketing field.

Marketing measures development and realization in Georgia should become a daily lifestyle, because this is a process, with the help of which supplied goods/services customer are created, perfected for raising living standards of the population. Marketing environment of Georgia is being established in the macroeconomic conditions, where the high statutory profit sectors of monopolistic competition is developed, and in low 
normative profit sectors - perfect competition.

The main result of competition in Georgia is not so much the direct price effect, but the possibility of goods wider choice and the benefits in trade field. Competition law defines marketing developing trends in Georgia and provides as single, industry competition, as well economy characteristics transparent picture.

Current marketing development problems in Georgia should be noted as social marketing development in the low level. Social marketing should be focused on solving population social, environmental, welfarerelated problems. Social marketing concept implies formation of strong social mechanisms, business and the public interest integrity and developing quality of life of population. The concept development in Georgia started several years ago.

If before, the marketing strategy main goal was company's profitability further growth, at the modern stage main focus is given to customer sustainable, partnership cooperation formation and maintenance. Social marketing problems research are conducted in Georgia for many years. However, in recent years the social marketing interventions, in terms of solving some social problems, have been implemented. Accordingly, social marketing research in Georgia moved to a new level.

Social marketing of Georgia includes consumer attitudes, consumer's behavior transformation process supporting forms of discussion, social marketing role emphasize in Georgian society. Great attention should be paid to the role of social media in Georgia for business development, which is the most important aspect of social marketing. Social networking special role is that it is interactive, which allows customers to make contact with the desired company, ask them questions and receive answers. This itself is effective for the company, as it has been notified of consumer opinions about the products. As a result, the company will be able to view the customer's correct response.

Social networks promote marketing activities popularization, encourage them, and with the least costs (sometimes even without the financial expenses) receive successful outcomes. The Georgian users often take decisions under the influence of social networks. Half of the Georgian population has no information about a product or service through the social networks, the fifth is the such a service user. In turn, the fifth of consumer with such a purchase method is dissatisfied, and the rest - via electronic channels are potential consumers of products. Thus, the social networks by fifth of Georgian population buying experiences has positive emotional effect.

Social marketing research field should become Georgia's business development challenges, the specifics of consumer behavior in crisis situations. According to marketing research of Georgian population it has been determined that there is connection between our country's economic crisis and the local users' interior motives. In particular, it has been revealed, what part of population affected the economic crisis, the nature of the impact of the crisis, what is the information regarding crisis, where do they take information, how consumer's attitudes towards the goods have changed, which method of economy Georgian customers use when making particular purchase, the products they will not economize on and what are their motives when buying expensive brands. The aforementioned is related to social marketing research as the crisis affects consumer behavior.

For any company establishment and maintenance of favorable long-term relationship is more simple and available, the more product helps to solve social problems. This applies both to the environment, as well as the safety and health problems. According to scientists social marketing programs success depends on many factors, but, as the research shows, from the most important factors should be noted the following: for Social challenges 
overcoming and in order to support relevant programs is important consolidation of state, business and population; for Social projects implementation is required selection of the right partner (including non-profit organizations as well); in order to solve Social problems is needed to choose target groups of consumers, their stimulation for adoption social ideas and programs, processing and realization of package of social measures.

There are many Marketing Development problems in the agricultural sphere. The aforementioned economy sector promotion is a key priority for the government. Special fund has been founded, ongoing free Plowing and sowing program, granted preferential agricultural loans. The exports look at this effort with suspicion, but besides how impressive can be a result, it will be overlapped by business development marketing problems in Georgian agricultural sphere.

Georgian government within the framework of agricultural assistance program initially started by giving free plowing and free fertilizers vouchers, after the low-interest and long-term agro-credits. However, these positive trends are accompanied by drawbacks: there is a misappropriation of funds, the farmers do not keep their critical attitude towards the program's goals and objectives. In their opinion: "only by tilling the program cannot work and cannot be revived the village, if the crop won't be sold. Agricultural products are perishable. Within two months after harvest if they cannot sell it, it should be thrown away.

Commonly farmers grow tons of watermelon, grapes, cabbage, apples, mandarins, oranges, lemons and other agricultural products. Before it was realized in Russia, Ukraine, Azerbaijan, Armenia and other postSoviet countries. Nowadays, because of military, political, or other reasons the exports stalled. Harvested agricultural products (crops) have realization problems in regions, districts and villages. Against this background, it is necessary to submit agricultural products near farmers living area, their processing in agro-industrial centers and prepare for selling in fast food outlets, restaurants, hotels and other retail-trading networks.

If in Georgia grown agricultural product delivery, processing and distribution costs is higher than the ready-finished agro-industrial products - canned, pickled and jams market price, the difference subsidizing will be much more logical than the free fertilizers and free tractor program, preferential agricultural loans, etc. Because if a farmer does not have excessively picked agricultural products realization guarantee, no preferential agricultural loans and nor free delivery of fertilizers and equipment could solve marketing problems in this sector.

For Georgian agricultural production realization convenient is Russia, but overland transportation to the aforementioned country's market, are non-profitable (unprofitable) because of grocery products realization low prices. However, our country's government talks about agricultural production overseas export prospects. Government of Georgian exactly names as the realization problem solving Russian market as the local agricultural products selling market, but the right of access to the Russian market, after passing the complicated procedures, so far only a few types of wine and mineral water gained.

One part of economic Georgian experts is skeptical about the prospect of opening the Russian market. Among the reasons we can list: market politicization, strict requirements and corruption problems. Georgian agricultural marketing specialists do not share optimism towards the Russian market. They think that Russia strictly controls who and what enters the country. It draws attention to the existence of pesticides. If any of the pesticides will be detected in our country's agricultural products it cannot enter Russian market.

According to the efforts made in Agriculture marketing sphere in 2004-2016, the agricultural goods production has increased 
dramatically in Georgia. Our country's agricultural products cannot penetrate into international markets competitively, but as a result of right marketing measures country's co-operatives could sell more agricultural products in Western markets and get more profit, if the agro-industrial production quality will meet the Euro-quality standards. For example: Georgia between the hazelnut exporting countries holds second place and occupies this production realization world market $7 \%$ of it, but it turns out that the hazelnuts do not enter from Georgia in the countries, such as: USA, a small quantity is sent to Germany, especially with the United States Georgia according to trade preferences system - "GSP", while the European Union benefits "GSP+". These systems Georgian products gives the possibility of low customs duties or even no customs exporting. To use this or other opportunities agricultural products business experts consider proper packaging, dealing with logistics problems and Georgian agricultural products advantages promotion by advertising right marketing organization.

Thus, the successful export of Georgian agricultural products generally depends on the competitiveness of the products, as well as certification according to international standards, dealing with logistics issues, and especially, properly targeted marketing system. To conclude Georgian sectors won't be formed a competitive environment, the need for marketing development is pointless. This is caused by the fact that monopolists do not need marketing "tricks", as the Giants achieve success by monopolizations as well.

While a farmer via agricultural cards can cultivate the land for free, but farmers help such an approach is not adequate. Government should help the village in another direction. Almost all of the regions have the difficulty with the harvest realization and they throw away their harvest to landfill. Naturally, there are problems with the harvest. Between the agricultural development marketing problems, the greatest difficulty is crop realizations.

Only tilling the land, which provides agricultural assistance program, the village could not be revived, if the crop is not realized. Harvested yield storage and realization a common problem of all farmers. Tangerine and grape producers faced realization problem every year. For example, the entire harvest is spoiled in Akhaltsikhe. Farmers cannot sell cabbage or cannot throw them in street, because they are afraid of penalties, spoiled crop taking to landfill is related to additional expenses.

Georgia turned into disadvantage compared to other countries by joining the world trade organization, our country in a WTO is accepted with the rules, that is not acceptable to our country. Many types of agricultural products (onion, garlic, apples, etc.) enters from Turkey, Iran and other countries, while our country ecologically pure products remain unsold. The emergence of aforementioned problems is due to incorrect marketing policy of the government. One such marketing problem is product import in dumping price.

The fact is that our government has signed with various countries cooperation absolutely different regimes. For example, if with one of the country our country's entrepreneurs are not entitled with certain regime export product to their market, the partner country has a right to bring according to this regime its products in our country. Therefore, it is necessary to protect Georgian production from import.

One of the marketing development important problem in Georgia is that our country's realization market is "inundated" with poor quality, cheap products. Accordingly, Georgian manufacturer, whose product is relatively of high-quality, expensive to produce, so the Georgian farmers find it difficult to sell. In addition, our country's one of the most important marketing problem is that, there is not developed relevant communication between cooperatives, farmers 
and agricultural products customer, as the rural population has communication difficulty. One of the marketing problems in Georgia is search of consumer market. In some places tangerines get rotten, in other - potatoes, grapes or apples.

Towards the imported products quality should be tightened control. Some experts believe that the import restriction will result production shortages, rising prices and quality worsening. The second part of the researchers suggests the product only temporary rise in price and has great hopes for the agro-cards, which gives farmers free plowing and sowing possibilities. The majority of experts are skeptical to the aforementioned projects.

One of the most important marketing problems of Georgian economy development is the fact, that there is intellect problem with our farmers, which this grown products processing, sorting and export to new markets. This area is to be used existing resource.

At the stage of the development on which level is our country's agro-business, severe marketing problem is harvested product realization, which eradication is significantly dependent on the West consumer market creation, when for marketing problems irresolution is accused predecessor government, this means that the current government cannot resolve the raised problem and accordingly the situation cannot be improved.

Thus, in the economic development of Georgia the great role should play marketing. As The firm production and realization activity management system, which should focus on consumer demand satisfaction. In our country existing marketing system should make entrepreneurs focus on customers, in order to turn them into purchasers and ensure in the firm's long-term success.

As Georgian marketing environment analysis shows, the Georgian business success largely depends on the quality of the marketing activities. That's why marketing should actually be considered a guarantee of the successful functioning of our country's firms, the study of which is necessary for those who are operating in the fast-changing market conditions. Pricing policy implementation in Georgia should be marketing realization function sub function. Competition in our country has developed by pricing methods preferred usage compared with non-pricing methods. It was characterized for free competition period. Price competition is used between the competition of oligopolies and firm-outsiders in our country.

Georgia-based firm-monopolists are mainly use open pricing competition such methods, as: a temporary reduction in prices, internal cartel agreement on import prices, a sharp decline in the price of new products and as well inventions patent protection at the international level. For example: the pharmaceutical, electronic and chemical industry products. In addition, hidden pricing competition is carried out by offering services and sales better terms. It should be noted that in modern reality of Georgia, non-pricing competition methods prevail pricing methods. Besides quality factor review from product price by abstraction is less available, accordingly, the price role is quite big in marketing.

The post-Soviet era retail trade network was divided into two types - the state and cooperative property. In recent years, together with the reduction of action arena of ownership of above forms, gradually increases role of private enterprises, joint-stock companies and other forms of ownerships. Retail-trade network classification is necessary for the sense in which a group of enterprises performing certain marketing decisions. The latter, in turn, is a comprehensive set of measures, notably in key issues, such as: the selection of the target market, the range of goods, forms its sales and pricing.

For economic development of Georgia via marketing is needed to explore market demand-oriented production and sales management unified system in constant movement and interconnection. Our country's companies marketing processes management can be regarded as a firm, coordinated action 
of its goods favorable exchange establishment to the buyer. What measures are needed in order to reach the local product competitiveness growth in Georgia, accelerating progress in foreign markets, to extend the life cycle, reduce costs and increase profits?

This requires both our government and local firms had a marketing management outlined, unified concept. Marketing management concept is unity of views, which proves particular measures performing feasibility. Creation of new product for Georgia should become an effective tool for competitiveness. For aforementioned is needed to divide target audience into classes of users, and then develop a marketing program, to outline its goals and objectives. When exporting our country's new products should be given great attention to its quality, consumer tastes, as the market provides information to entrepreneurs about the taste.

Despite certain success, Georgian economy is still in crisis. It is very critical marketing, especially trade issues, as far as in this area is concentrated economy drive core. These problems are not purely economic in nature, but they have enormous social load. Economy should be socially oriented, because any economic activity, must be useful for society, but cannot be rejected strategic economic interests. For Social problems temporary neutralization is required global approach.

Conclusions and further prospects of the research. There are following problems in marketing development fields in Georgia:

1) the irregular, it means External trade problems;

2) low quality, counterfeit goods trade;

3) non-accounting of small traders, problem of tax collection;

4) large commercial enterprises crisis.

Obviously, this list is only part of the problems that occur in Georgia in terms of marketing development. All the abovementioned marketing problem, in turn, causes number of social problems and often leads to catastrophic results.
There were lots of attempts to solve marketing problem initiative in our country, which was initiated by state as well private agencies. Unauthorized external trade eradication hindering main problem street vendors belong to the most vulnerable sectors of society. Trade with Low quality, Counterfeit goods is linked with small vendors' onregistration, their economic activities controlling problem. In Large commercial enterprises is relatively easy to check the goods nomenclature. Small vendors such monitoring would only cause corruption in their monitoring services. Unauthorized trade analysis shows that this area has become a source of the other two problems.

Large commercial enterprises require taxes, especially the VAT reduction, because the taxes paid in the form of VAT reduces their production pricing competitiveness, by unauthorized street vendors, without the VAT, against the background of selling good cheaply. Logical chain suggesting that the problem of unauthorized external trade is relatively low than profitability of large enterprises, we know that the external trade of goods makes a lot turnover, before it reaches the customer, several trading profit is distributed to some vendors in aforementioned turnover, but each of them is still satisfied.

In order to eliminate the sidewalks harassment, streets contamination and many other related problems caused by external trade, it is necessary it was less cost-effective than the large commercial enterprises activity, but unauthorized external trade eliminations, its limitation in the administration legal frames (which large and retail traders put in the same conditions and would result in trade capital consolidation, profitability increase) is unresolved acute social problem. Evading the taxes is natural aspiration of taxpayers, but unauthorized vendors accounting and their business administration is even more severe problem. However, unified taxation has fiscal significance.

Unauthorized external trade is hazardous 
for vendors' health, ecologically pollutes environment. So this area needs improvement. Of course it will be a painful process, especially for vulnerable groups. Nevertheless, the government rejected the benefits, that will be economically difficult to compensate. The law supremacy principle, should be equally applied to both the unauthorized street vendors, as well as the large traders. Excessive tolerance is like a boomerang for country's economy. The Government of Georgia should set up a joint controlling body or its activities controlling additional body, because tax payment is a primary civic duty.

\section{References}

1. Gvenetadze, S. (2009), "The modern concept of marketing, its development real situation in Georgia and the need for improvement", [Online], available at: http://www.nplg.gov.ge/.../library.exe?.. (Accessed 10 May 2017).

2. Alimbarashvili, D. (2011), "Goods rotation problem in our society", [Online], available at: http://www. nplg. gov. ge/.../library.exe? (Accessed 10 May 2017).

3. Nugzar, T. and Charita, J. (2014), "Challenges of social marketing in Georgia", [Online], available at: https://www.tsu.ge/science/?leng=ge\&jnomeri=5\&lcat=jurnal\&tid=12 (Accessed 10 May 2017).

4. Mchedlidze, K. (2013), "Marketing Problems of Agriculture of Georgia", [Online], available at: http://www.radiotavisupleba.ge/a/soplis-meurneobis-marketingi/24996842.html (Accessed 10 May 2017).

\section{Бібліографічний опис для цитування:}

Katamadze, G. Sh. Marketing development problems in Georgia / D. Sh. Katamadze // Науковий журнал «Економічні горизонти». - 2017. - № 1(2). - С. 12-19. 